\title{
Perception of Spirituality among Substance Addicts with Incarceration Experience: A Phenomenological Study
}

\author{
İsa Ceylan ${ }^{1 \odot}$ \\ Ankara University
}

\author{
Liam Metcalf-White ${ }^{2}$ \\ University of Chester
}

\begin{abstract}
This paper examines the role of spirituality in a recovery context by drawing on qualitative research conducted at a residential recovery community in North Wales, United Kingdom. The study aimed to examine perceptions of spirituality among exprisoners and people identifying as in recovery from addiction. The researchers explored ideas of "spiritual coping" and "spiritual wellbeing" in terms of meaning, purpose, connectedness, forgiveness, and peace in addiction treatment programs influenced by 12-Step models, for instance, Alcoholics Anonymous (AA). Also, this paper focuses on both spiritual counseling services shaped by pre-determined meanings and values and secondly, on individuals' perceptions about spirituality through the language of desires, needs, and expectations. The data for this research produced from five semi-structured interviews with male individuals who had recovered from their addiction and had practised some custodial life. To discover the common context of different perceptions of the language spirituality, the data was coded by the first and second loop encodings from the data analysis methods used. The central schemes that appear as "Spirituality in Experiences, Spirituality in Values, Spirituality as Meaning/Purpose of Life, Spirituality as Attachment, Spirituality as Coping Mechanism" have been evaluated within the framework of the concept of spirituality. In the conclusion of this study, it was observed that spirituality was used as a coping mechanism for buffering the sensation of hopelessness and powerlessness often experienced by people in active addiction.
\end{abstract}

Keywords:

Addiction $\bullet$ Spirituality $\bullet$ Recovery $\bullet$ Prison Experience $\bullet$ Values

\section{Cezaevi Deneyimi Olan Madde Bağımlılarının Maneviyat Algısı: Fenomenolojik Bir Çalışma}

$\mathrm{Bu}$ çalışma, Birleşik Krallık sınırlarında bulunan Kuzey Galler'deki bağımlılık rehabilitasyon merkezinde yürütülen nitel araştırmalardan da yararlanılarak maneviyatın iyileşme sürecindeki rolünü incelemektedir. Çalışma, önceki yaşamında hüküm giymiş olup aktif olarak bağımlılık tedavisi gören bireyler arasındaki maneviyat algılarını incelemeyi amaçlamaktadır. Araştırmacılar, 12 adım geleneğini esas alan Adsız Alkolikler (AA) gibi bağımlılık tedavi programlarından etkilenen bireylerin anlam, amaç, bağlılık, affetme ve huzur gibi "dini/manevi başa çıkma" ve "manevi iyi oluş" ile ilgili fikirlerini araştırdılar. Ayrıca, bu makale hem önceden belirlenmiş, anlam ve değerlerle şekillendirilmiş manevi bakım hizmetlerine; hem de bireylerin istek, ihtiyaç ve beklentileri çerçevesinde kullandıkları dile ilişkin maneviyat algılarına odaklanmaktadır. Bu araştırmanın verileri, bağımlılıklarından kurtulmuş ve bazı gözaltı deneyimleri yaşamış erkek bireylerle yapılan yarı yapılandırılmış beş görüşmeden elde edilmiştir. Maneviyat diline ilişkin farklı algıların ortak bağlamını keşfetmek için veriler, veri analizi yöntemlerinden birinci ve ikinci döngü kodlamaları ile kodlanmıştır. "Deneyimlerdeki Maneviyat, Değerlerde Maneviyat, Yaşamın Anlamı / Amacı Olarak Maneviyat, Bağlanma Olarak Maneviyat, Başa Çıkma Mekanizması Olarak Maneviyat" olarak ortaya çıkan merkezi şemalar, maneviyat kavramı çerçevesinde yorumlanmıştır. Bu çalışmanın sonucunda, maneviyatın, aktif olarak bağımlı olan bireyler tarafından sıklıkla, yaşadığı umutsuzluk ve güçsüzlük hissini tamponlamak için bir baş etme mekanizması olarak kullanıldığı gözlenmiştir

Anahtar Kelimeler:

Bağımlılık • Maneviyat $・$ İyileşme $・$ Cezaevi Deneyimi $・$ Değerler

\footnotetext{
" The authors were supported by The Higher Power Project \& CSARS Group Bangor Recovery Project. This study was supported by The Scientific and Technological Research Council of Turkey (TUBITAK) 2214/A. This paper was presented as an oral presentation at the II. International Spiritual Counselling and Care Congress held in Istanbul on 22-24 November 2018.

1 Correspondence to: Ankara University, Divinity Faculty, Department of Psychology of Religion, Beşevler Ankara, ceylanisa@gmail.com 2 University of Chester, Art and Humanities Faculty, Department of Theology and Religious Studies, l.metcalfwhite@chester.ac.uk

Citation: Ceylan, İ., Metcalf-White, L. (2019). Perception of spirituality among substance addicts with incarceration experience: a phenomenological study. Spiritual Psychology and Counseling, 4, 201-218.

http://dx.doi.org/10.37898/spc.2019.4.3.084
} 
Addiction represents multidimensional, biopsychosocial and spiritual, brain and behaviour conditions that affect millions of lives around the world. Among these conditions, spirituality stands in a different status (DiClemente, 2018). Research shows that spirituality has become an important topic in today's world, especially in the addiction treatment (Cook, 2004; Kelly, Stout, Magill, Tonigan, \& Pagano, 2011; Galanter, et al., 2007). Spirituality is frequently described as a multi-dimensional concept that relates to individuals, families and the social lives of human beings. Spirituality is described as also "existence a positive and original human being in entire parts of our lifecycle (Booth, 1987). According to Cook (2004), spirituality is a characteristic, theoretically authentic and common aspect of anthropological practice ascending both within the inner personal awareness of individuals and within societies, communal clusters, and traditions. It might practice as an association with that which is closely 'inner', inherent and individual, within the self and others, and/or as the association with that which is exclusively 'other', superior and away from the self. It is experienced as being of major or eventual prominence and is thus concerned with substances of meaning and drive in life, fact, and principles. This description advanced from a study of how the idea of spirituality used in the literature on addiction and spirituality; on the other hand it debatably applies similarly well to other parts. It highlights the generalization of spirituality as an individual aspect of the understanding of being human, at the equal time endeavouring to identify that this is still, however, a communally located phenomenon (Sims \& Cook, 2009). Spirituality encompasses the central of human beings and the lived-experiences with the transcendental characteristic that can be shared common qualities (Ozdogan, 2009, p. 19). A person's distinctive spirituality or spiritual approach is the way he/she seeks to discovery or construct, use, and enlarge individual meaning in the context of God or the cosmos (Wright, 2003; Culliford \& Eagger, 2009). The concept of spirituality has an extensive range of meaning, and so, it seems rather stimulating to make a precise description of spirituality. Owing to its ontology, it is seen as very noteworthy but apparent in different ways. Yet, spirituality is as much to do with disciplines and performs as with beliefs, attitudes or feelings. Fear, hatred, blame, and disgrace are characterized as drivers of addictive behavior to be contradicted (Dossett, 2017). It may contribute to understanding the meaning of attendants' experience. Spiritual experience may offer a 'safe bridge' to express feelings that might be too stressful to address directly (Shinebourne \& Smith, 2011). The lived experience of spirituality often crosses practically with other scopes of life experience for example marriage, prison life or job experience. Therefore, thematic patterns emerging from phenomenological examines would define broadly shared configurations of meaning as well as idiographic differences of these shared arrangements (Graham, McDonald, \& Klaassen, 2008).

Values are shaped according to the principles that guide us in life. The values were classified in different ways in the literature. In this context, beliefs, desires, 
characteristics of the group, ethical issues, importance, and priorities can be classified as periodic values (Mizikaci, 2015). Schwartz and Sagie (2000) describe individual values as situational goals and principles that are desirable, changeable and a guide for people in their lives. There is rising support to the awareness that spiritual values (e.g., patience, gratitude, forgiveness, hope ) and life aim to make an irrefutable influence on both physical and psychological health (Irudayadason, 2018). Centred on an understanding of spirituality, masses of interferences can be created that can involve patients by highlighting wellness and forestall amongst patients (Isaac, Hay, \& Lubetkin, 2016). As stated by the 2004 report of the World Health Organization (WHO), primary and preventive interventions achieve a success rate of $40-50 \%$ (WHO, 2004). On the other hand, there is a vital role of religious/spiritual beliefs and practices in alcohol and drug problems, including their role in the development, prevention, and treatment of these disorders (Koenig, King, \& Carson, 2012, p. 224). According to Culliford (2011), the spiritual themes can be stated as follows: Joy and wonder, reciprocity, meaning and purpose, life as a journey, death, religions, God and names of God, belief as a form of attachment, faith, love, non-dualism, two ways of experiencing time, an inner source of knowledge, mysticism, wisdom, unity body mind and soul, the avoidance of conflict, the language of spirituality, five dimensions of human experience, emotions-healing and growth, sacred universality, human stories.

Those who support and trail the 12-step technique of dealing with addiction recognize the significance of a spiritual approach openly. The best-known associations to practice this method are Alcoholics Anonymous (where it originated), Narcotics Anonymous. Narcotics Anonymous, e.g., labels itself as 'a non-religious fellowship, inspiring each member to encourage a personal understanding, religious or not, of a spiritual emerging' (Narcotics Anonymous, 2018). Twelve Steps are a group of principles, spiritual in their nature, which, if practiced as a way of life, can expel the obsession to drink or use drug and enable the sufferer to become happily and usefully whole (Alcoholics Anonymous, 2014). The twelve steps are a spiritual technique of living, destined honest thinking, not wishful thinking, broad-mindedness, a readiness to effort, and faith to receive (Dossett, 2013). They articulated endurance, acceptance, and self-effacement, and above all, the belief that a Power higher than myself could provision (Alcoholics-Anonymous, 2014, p. 356). The changeovers into and out of addictions do not follow deprived of the contribution of the addicted individual - the individual is complicated in how these influences are administered and whether their effect will be solid enough to overwhelm conflicting values and become incorporated into his or her value system (DiClemente, 2018).

A universal methodology of recovery (include spirituality) inspires development through self-exploration and suitable manifestation of feelings, recognition of severe 
emotional conditions, and learning further adaptive conducts to soothe and relief the mind, body, and spirit. However, it seems that connectedness, which emphasizes spirituality in twelve steps, cannot yet measured with existing theoretical models (Greene \& Nguyen, 2012; Dossett, 2015). To understand one's spirituality (defined at this time as one's values, beliefs, experiences, and a sense of drive in the world) is critical to any recovery program. The valuation of spiritual arrangement (and how it relates to one's substance support treatment providers) comprehends how each individual views him/herself in terms of personal means and value (Breslin, Reed, \& Malone, 2011). Procedures of change characterise the internal and external practises and experiences that permit individuals to transfer from phase to phase. The processes are the mechanisms that create and sustain the transitions through the steps and facilitate the successful completion of the stage tasks (DiClemente, 2018, p. 34).

There are many studies on addiction and change in the literature (DiClemente, 2018; Williamson \& Hood, 2013; Roman, Wolff, Correa, \& Buck, 2007). Also, lots of studies on the role of spirituality in addiction and change are also encountered (Al-Anon, 2015; Kelly, Stout, Magill, Tonigan, \& Pagano, 2011; Tonigan, N., \& McCrady, 2013). However, no direct study with a phenomenological model on the role of spirituality and perceptions of spirituality has been found on the intention of change and in maintaining change in individuals living in prison. These observations and the lack of literature have encouraged us to carry out this study. Thus, it can be said that a deficiency in the literature will be filled. Also, after the experience of the prison, it is thought that it will contribute to the projects and studies about the role of the spirituality for individuals who intend to change.

In this context, an interesting awareness developed about the meaning of spirituality. As one will see in this article, connectedness offered as a subject that recurrences itself unceasingly and becomes a repetitive theory in labelling spirituality. This awareness was about the perceptions of spirituality amongst individuals who had a prison experience. In North-Wales UK during the visits, while observing programs focused on religious and spiritual studies, we participated in the training and therapy groups of individuals in recovery from addiction at the Penrhyn Recovery House in Bangor, and Berwyn Prison in Wrexham. In the statements of health workers, there is an evaluation of spirituality as a dimension of their own experience (Cook, Powell, $\&$ Sims, 2009). For this reason, it was wondered whether there were any unique characteristics in the perception of spirituality amongst individuals who went to rehabilitation centres with the intention of change after the prison experience. During the observations in prison, especially in spirituality-oriented group meetings such as Alcoholics Anonymous or Narcotics Alcoholics, it was observed that the participants saw the spiritual experience as a process of change, and as a strong relationship with values meaning and purpose of life. 
For many of them who have experienced both prison life and active addiction, spirituality is perceived as a necessary framework in which to anchor rehabilitation and recovery. In this context, the study aimed to examine perceptions of spirituality among ex-prisoners and people identifying as in recovery from addiction. The primary intention of this paper was to identify and interpret how different individuals in recovery from addiction expressed the term spirituality. Phenomenology was used in this study to investigate and examine how individuals perceive and experience spirituality. It expected that this study might offer and arrangement an empirical foundation for the expansion of a theoretical and methodological background for future researches into addiction and spirituality.

The researchers sought answers for the following questions:

1. What are the participants' experiences with addiction?

2. Can experiences be evaluated as spiritual?

3. What is the place of spirituality in finding the meaning and purpose of life?

4. What is the significance of values in spirituality?

\section{Method}

\section{Design}

Studies have recently shown a growing trend of individuals expressing themselves as spiritual rather than religious (Fuller, 2001; Heelas, Woodhead, Seel, Szerszynski, \& Tusting, 2005; Woodhead, 2010). Besides the existence of many factors affecting this, here the research focused on the concept of spirituality as a phenomenon. This study was designed with a phenomenological model from the qualitative researches models (Moustakas, 1994). Phenomenological investigation is an approach of examination in which the researcher classifies the core of human experiences about a phenomenon as designated by participants. Accepting the lived experiences challenges phenomenology as a philosophy as well as a method, and the process encompasses studying a minor number of subjects through wide and continued engagement to develop shapes and associations of meaning (Creswell, 2009; Moustakas, 1994). Phenomenology permits investigative and construing a number of experience, such as people's perceptions of spirituality.

The interpretation of the data in the phenomenology research aimed at extracting meaningful scientific data from the participants' experiences. Scientific data have a conceptual diversity that can explain the phenomenon. Phenomenology presentations are mostly quoted directly from participant statements. It is not aimed to reach general 
and definite results in phenomenology studies. Instead, explanations and analyses are carried out that provides more focus on the research problem or the subject being examined. With these analyses, a new look at the literature and a new, unrecognised area of research are produced (Moustakas, 1994).

Similarly, phenomenology research has no intention to test the validity and generalizability of theory by experimenting with the development of explanatory theories and investigating phenomena (Casey, 2009; Baltaci, 2018). The task is relational, embedded in everything that goes on between the professional and the participant (Poole \& Higgo, 2006). With a focus on one event, we have been capable of affording an in-depth and nuanced overview of the participants' experiences with spirituality (Pnina \& Jonathan, 2009).

\section{Working Team and Participants}

The authors of this paper joined the Higher Power Project and Chester Studies of Addiction, Recovery and Spirituality (CSARS) Group in 2018 to explore Twelve Step recovery programmes and spiritual recovery from addiction (CSARS Group, 2018). The Higher Power Project is an initiative to record and map the variety of understandings of 'Higher Power' or 'power greater than ourselves' used by individuals in recovery from addiction to alcohol or drug/medicines (The Higher Power Project, 2018; Dossett, 2013). CSARS Group develops community-based projects planned to confirm that the Higher Power Project research and other research results are conveyed to the occupations involved in the dealing of addiction and to people in quest of recovery. This study supported by The Higher Power Project and North Wales Recovery Community-Penrhyn House (NWRC) in partnership with local agencies and with the cooperation of Alcoholics Anonymous (Alcoholics-Anonymous, 2014), Narcotics Anonymous (Narcotics Anonymous, 2018) and SMART Recovery (Li, Feifer, \& Strohm, 2000; Horvath \& Velten, 2000). The projects provide a framework, support and knowledge to volunteer participants wanting to try to achieve abstinencebased recovery through 13 weekly group sessions. NWRC intentions to produce a linkage of recovery groups that help persons to create and uphold self-discipline from long term drug abuse. Based on the perceptions of joint assistance, persons reinforced to progress the optimistic maintenance linkage and social capital necessary to produce meaningful lives, contravention the cycle of material misuse, law-abiding and homelessness (North Wales Recovery Community, 2018).

The data for this research produced from five semi-structured interviews with people who had recovered from their addiction and had practised some custodial life. Participants did not intent to share their demographic or characteristic information. But all of the participants volunteered to participate in the research and were men. The sampling approach planned to mark appropriate participants in Penrhyn 
Recovery House in Bangor-UK - participants who are in active recovery progression and have experienced some kind of spiritual transformation in programs for example Alcoholic Anonymous or The Higher Power Project. The participants designated via purposeful criterion sampling along with the following conditions: a history of addiction and prison experience; joining to practise of some kind of spiritual recovery plans; voluntary to participate, and accessibility for conceivable follow-up enquiries (Baltaci, 2018). In the scope of this study, no personal data of any participants were used. While coding the individuals, "P" was used for each participant.

\section{Materials and Data Analysis}

This paper examines the role of spirituality in this context by drawing on qualitative research conducted at a residential recovery community in North Wales, the United Kingdom, and draws on a model of phenomenological interpretation to investigate the language of spirituality among people who had previously been in prison and are currently in recovery from addiction. To discover the common themes of different perceptions of the language spirituality, the data was coded by the first and second loop encodings from the data analysis methods used.

The primary materials of data collection are semi-structured interviews. Researchers made a questionnaire to use at interviews. The opinions of the three members of the CSARS Group on the draft questionnaire form were taken, and the necessary arrangements were made. The voice recordings were decoded and encoded with the NVivo 10 package programme. Aiming for reliability and validity, two external researchers were gathered to independently assess the responses to the same data and code for the essence of the spirituality (Manning, 2012) in recovery from addiction (Heale \& Twycross, 2015). Two other raters autonomously rated excellence of these studies in a parallel manner. The reliability of the quality ratings was 0.80 for consistency, and both indicating acceptable degrees of reliability. Direct quotations should be of flexibility and validity that makes it easier to extract meaning from data. The themes and sub-themes obtained at the end of the encodings can also be included in the presentations (Moustakas, 1994).

CSARS Group has undertaken the process of contacting the Penrhyn Recovery House and obtaining the necessary permits. Individuals with imprisonment experience were selected from those staying in the recovery house. Only 5 male participants volunteered. The mean duration of treatment was 6 months. The interviews were conducted in the meeting room in the recovery house. The present interviews were conducted and audio-recorded by the authors in July 2018. The interviews took about 10-15 minutes on average.

During each interview, they addressed some subjects including spirituality, 
spiritual values, transformation and prison experience. This study tried to reach the language of spiritual experiences of ex-prisoners in recovery from addiction through the following questions:

- What does spirituality mean to individuals in recovery from addiction?

- Is the recovery process a kind of spiritual experience? Why

- What does prison life look like?

- Do values such as patience, hope, and forgiveness, have any meaning for you? How?

- While encountering a problem, does spirituality help? How does it work?

\section{Findings and Discussion}

Following Table 1, researchers analysed and interpreted the statements of the participants. The analyses were classified into specific themes. Several themes were collected under central schemes. It emphasises the main dimensions of the perception of spirituality, as described by these participants. The main themes have been identified as "Spirituality in Experiences, Spirituality in Values, Spirituality as Meaning/Purpose of Life, Spirituality as Attachment, and Spirituality as Coping Mechanism". These fundamental themes abstract spiritual inquiring as a voyage that is entrenched in convincing understandings that are recognised as noteworthy in guiding life. Interrogative procedures are a valuable thread entrenched in regular life, whether or not they are in the forefront. Spirituality is a answer both to impactful proceedings and to activities developing from our hearts (Matthew D. Graham, 2008). The following statements and explanations include the analysis of the spiritual livedexperienced and values by the participants.

Table 1

Thematic Framework

\begin{tabular}{ll}
\hline Themes & Sub-themes \\
\hline Spirituality in Experiences & $\begin{array}{l}\text { Change Experiences } \\
\text { Experiences in the Prison } \\
\text { Experiences in a Daily Life }\end{array}$ \\
$\begin{array}{l}\text { Spirituality in Values } \\
\text { Spirituality as Meaning/Purpose of Life } \\
\text { Spirituality as Attachment }\end{array}$ \\
Spirituality as Coping Mechanism
\end{tabular}

Theme 1: Spirituality in Experiences 
Change Experiences. P1 seems to have an insightful personality about his responsibilities. He does not attribute the reason for his imprisonment to external factors. He expresses that he has used his experience of imprisonment to allow himself to gain awareness. It is also stated that this experience was a transformation for him:

Well, it's not very good. But, obviously, if you've done the crime, you do the time. I've never been wrongly accused of anything; I've never been to jail for something I've been wrongly accused of anyway - it was mostly fair. But, like I said, the last time gave me enough time to think. It's a reformation, that's what they go there for. It helped me, I suppose.

In the process of rehabilitation, $\mathrm{P} 2$ is eager to experience what he has learned and to bring it into life. He seems to be very happy and satisfied with seeing his experiences in life. He does not hide his excitement while describing his acquired life skills. It is understood that he turned the rehabilitation process into a positive opportunity for transformation:

P2: ... and if you're having a tough time, you go and speak to them in the office and say, 'look I'm starting to struggle', and the advice is there. Like, I'm doing something with the "attendant" now, that I don't really want to talk about, that happened to me in my past, and the support I'm getting is unbelievable. I'd never thought I'd regret it like I am - it's amazing. I'm able to actually deal with my life - it couldn't be better. I couldn't ask for more; I'd feel cheeky if I did.

The continuation of the old life was expressed as a significant obstacle to change. It was emphasised that for transformation, everything should be differentiated. In particular, it has been said that the changing of lifestyle is the most crucial step:

P1: It's not like you don't have access to stuff when you're in there-there are new things all the time; I just didn't want to when I was in prison. It was weird. It proves that I could change my routine, clearly, as long as I kept occupied and busy, then it is obviously achievable. All depends on how much you want to put in.

P3 had a period of recovery for 11 years, and he has found that the 11 years period has been helpful for his recovery. He experienced different lifestyles, different friends for reformation. He has also stated that although rehabilitation programs have some contribution, most of them are a waste of time:

You have to move away; you have to do everything differently, everything. I moved from here to mid-Wales, started a new family, decent job - £1000 a week, nearly - had my own home, a bit of land, horses - you know, just kept busy. All my friends were professional people, fireman, this and that... keep busy. Change your lifestyle completely; otherwise, you don't do it - that's from experience. I mean, I've done nearly five rehabs, all over the country - waste of time. It's definitely not a detox. The rehab part of it, I see bits from other things. There are courses there like "SMART" and this and that. But, there's no point; you're going to the counselling, the classes, and then you go straight back to a cell that's full of drugs - so there's no point. 
The contribution of the mutual aid groups implemented at the Penrhyn Recovery House to the individuals in the recovery process is often emphasised. In particular, programs such as The Higher Power Project, AA, and NA have seen much more useful than other structured training programs. Individuals participating in the program help themselves as well, when helping others. Moreover, they can find themselves in someone else's experience, therefore offer an active engagement rather than sitting and listening.

P1: I'm helping facilitate it now. I get a lot out of that. I get a lot more out of it now. I'm actually teaching it because I force myself to understand it a lot more than I was; it's hard to explain something to someone if you don't know yourself.

Experiences in the Prison. The programs implemented in recovery houses are similarly implemented in prisons. It is stated that prison is a suitable environment for thinking. Awareness was shared that the same lifestyle gave rise to the same mistakes. In other words, the source of the problem can be seen as the repetition of a dull and monotone lifestyle.

P1: I did the SCP skills programme, and that was a bit similar to SMART Recovery, which is why I took the SMART Recovery group quite a lot, and because you got a cost-benefit analysis as well. It just helped me think. I was told 'You can't do the same thing and expect different outcomes' - So, I was doing the same thing, the same routine when I was released from prison and was wondering why I was going back. I see it as two me's: when I'm drunk and when I'm sober, I'm two different people. The drunk me does the crime, and the sober me has got to do the time.

The experience of prison is often considered useful for the participants, even though they do not want to reconsider and live in those days. Individuals with prison experience say that they can find enough time to think and look at their lives again. But they still cannot go without saying that despite all the opportunities in prison, the prison is boring. On the one hand, it means that there is sufficient and appropriate time for a spiritual experience, transformation, and staying clean. P3 put himself in jail for short periods to get clean, while he was in jail, he came off his medication. P5 said the experience of prison was not too bad, at first he struggled, but towards the end of his sentence, he did not want to leave. In this context, prison experience allows the individual to quest his values, meaning, and purpose of his life.

P1: I was in jail for seven and a half months last time. I had enough time to think and thought, 'I've had enough'. Though, when I got released, I went back into the same routine. P2: I started off at $15 \ldots 15$ when I'd done the offence and 16 when I went to prison, in Walton. I've seen the changes from the old slop out days to having the toilets and that. But, you get used to it - it's just a way of life. You don't feel it any-more. I've had confrontations ... drugs, even some of the screws bent, you know what I mean? Paying them to bring stuff in. It's just... looking back is not a good way, but at the time you think 'Oh yeah, look at me'. But, it's all twisted. My experience with prison has been good, I thought at the time, but not, you know? Fights, accusing people of doing this, doing that, doing the other - you end up causing trouble, just for something to do. It's 
boredom, even though Prison of Altcourse has got the pool, the snooker, and the table tennis. But because it's there every day, and nothing else to do, it's boredom. I'd rather, prefer, to do my jail at ... - you know where you were; that's not your choice, though. So, yeah, I started quite young.

Experiences in a Daily Life. Participants, who were struggling with alcohol or substance at a very early age, stated that most of their lives were homeless, living on the streets and not having a quality life. In addition to family problems, they suffered from other health issues. Their relationship with their environment seemed problematic.

P1: I was homeless, living on the streets, on and off, for about five years - between jail and the streets. P2: It's also because I was made homeless. My Mum had a bungalow, and they said I couldn't ... So, when they evicted me, and I had to live on the streets, it was all around me. So, I ended up doing it, doing the drugs again, because everybody was... P4: Through my early thirties - around the time I got married - I started to have big problems, causing problems for other people, but also causing problems for me. It progressed all through my thirties... In my forties it started to get really out of control: bad things were happening, I was starting to lose... starting to cost me more money, my marriage went, I moved out of the family home. I chose alcohol and drugs over everything else. Stopped work, stopped doing any work. Towards the last few years, I've become a binge drinker in my attempts to stop... But it was sort of around about 40 when I really had a genuine desire to stop but I couldn't. But alcohol was the one that was killing me. Hospitalisations had begun around 2001, so I had six to seven years of that before they finally stopped, in 2008 .

Individuals who stated that everything goes well as long as they practice what they have learned in the program in the prison can remain sober and clean. When they are bored or not kept busy, they say that the recovery process will be a problem.

P1: You've got to work the programme; if you don't work it, you'll leave with the same skills you come with. Yeah, it's so easy to give yourself over to a routine for years; it's not going to be easy to stop - to just get sober, and that's it. You've got to work at something.

Alcohol and substance use cause many losses. Participants stated that they lost a large part of their property and staff, especially their health and dignity. After deciding to be cleaned and to get recovered, they stated that although they succeeded, they could not save themselves from stigma. Maybe everything can be won in a way, but it is emphasised that it is challenging to recover self-respect, dignity, and selfconfidence. In this context, P2 says:

I had a car mechanics and had five cars outside my house - that's what I used to do: buy and sell cars. I used to make decent money; this was after work and that. But, slowly, everything went: one car went, another car went, and in the end, my tools went - everything. I lost a lot. But, you know, most of all, my self-respect - that was the biggest loss. Everything else can be replaced, but the respect is harder to get back, isn't it? You don't realise how self-destroying you are. You think people are looking at you, they don't know, even though I was getting myself clean - it was a mess. You lose everything. 


\section{Theme 2: Spirituality in Values}

Participants who underlined the contribution of values in "coping process" emphasised the importance of concepts of hope and patience. Also, those who indicate that the value of hope gives comfort to them seem to grasp the importance of working as well. For this reason, it is understood that they act by integrating the value of patience with hope. In this context, P1 says:

Hope, hope, definitely. Patience, I've put... this stuff is not going to be done in a day. When you're in addiction, you want everything, there and then, you need it now; when you're in this recovery, you desire stuff, you desire to hope. You just want to relax... you're hoping for the best but yet you're working at it - you know it's not going to be done in a day.

Participants living with values can leave their suffering in the past and continue their way with hope and happiness. As the research has shown, the coping skills and well-being levels of those who live actively and whose values are engaged in their lives are generally well and better than the average of society. In this context, P1 considers:

I've done enough misery now; I deserve a bit of happiness. But happiness is a reward for hard work, isn't it? So, we'll get there. I'm happy enough as it is, but I'll take a bit more.

P4 thinks that truth and self-honesty are the most important values. He also adds not lying, brave and courageous to these values. P5 describes all values as spiritual in nature, and sees values as recovery. He also points out that values must become life skills in a holistic structure, not separately.

P4: Truth. The truth is the main one. I try to listen... But yeah, self-honesty and being honest with another human being, I think - they're the big ones. But, trust, trust is a big issue for me; still is. But I think, the truth, self-honesty are certainly, and basically, you know, a honest way of life: to not lie, to not steal, to not cheat, to not bully, and to try to stand up and not be such a coward - not run away from everything and have a bit of courage, I think it's important.

P5: All the values are spiritual in nature. Values to me, are the be all and end all of my recovery. Every day I try my best the incorporate these values as life. Skills that I may use.

There is an awareness of helping others for self-help in mutual aid groups. This consciousness also manifests itself in the concept of life skill as giving to others and assisting others in social life. P4 said that he is just trying to provide a service, just trying to help others; without being a doormat, just trying to be useful. Value-based gains from structured or mutual aid groups can be helpful as long as they are done in conjunction with an active life. Participants often emphasise the importance of making values a priority and mobilising them. P1 says the following:

Especially when it means something to someone - definitely. You see a few lightbulb moments go when you talk, and it's like 'They've got it! There's a difference between sitting there and listening and sitting there and putting things into practice. You can learn all these skills and not put them into practice, and it means you might not succeed. It is about making changes, it is 
about prioritising this recovery before everything else, and everything else will follow - you can have anything, as long as you stick with this.

\section{Theme 3: Spirituality as Meaning/Purpose of Life}

The participants' perception of spirituality manifests itself as the meaning and purpose of life - everything that adds value to life is expressed spiritually. The priorities of individuals constitute the values for themselves, and values are discussed in the spiritual framework. P1 perceives his deep thoughts about the meaning and purpose of his life as a spiritual. Having control of his/her life and to find a solution is considered spiritual.

P1: ... I take half an hour to an hour in the morning just laying in bed on my own, gather my thoughts, and it sets a lot better mood for the day - that's spirituality to me. Some people do mindfulness and stuff like that; it's my form of mindfulness I've got. I've got an hour to work solutions. I've got longer if I wanted; I don't have to do anything. I don't have to get up and get a bottle; just got to do whatever I want to do. The choice is great.

Keeping the values alive can sometimes affect the religiousness positively. Having the meaning and purpose of what is giving value and trying to be included in life shows itself as a motivating factor in the recovery process. It is seen that the individual is the owner of insight, taking responsibility for his / her actions and giving positive meaning to the healing process as a result of experiencing spirituality. In this context, P2 expresses the spiritual sentiments and its outputs with a sense of astonishment:

You think that night you say a prayer, and something happens the next day, Wow, that something I'd spoken about last night, that I was talking in my prayer about - whether it be coincidence or not - you think, more than once, it has got to be more than a coincidence. Things happen for a reason, and the reason is to get yourself on the right road, isn't it? To get yourself my side. It's just... I've gone to my room, crying my eyes out about the things I've done, seen, the way I behaved, and I don't like that person. A couple of people in here have said you need to learn to like yourself before you can like anybody else - concentrate on yourself first. It is, you've got to become friends with yourself, and that's what I ask the Lord every day, every night. Sometimes I do it in the day, you know, Help me through this, and you do - you find the strength. Yeah, it's amazing.

The individuals in the process of recovery state that they meet their attachment needs in various ways. Individuals who meet their needs of attachment by connecting to God, their friends, family, recovery groups or some values evaluate this process within the framework of spirituality. Participants indicate that the connected entity gives them power and hope and emphasize the importance of communication in recovery. This spiritual process is sometimes discussed in a religious framework and is sometimes expressed in terms of values independent of religion concept. P2 says:

I've found myself every night now. I have a little prayer. I talk to my Mother, my Father, I ask the Lord, obviously, to keep me strong, to keep the bad thoughts away, and hope I do well. Also, 
sometimes, when we're in a meeting, I hear someone saying, They had this episode or that, and I think, Oh wow, why can't that be me, and it's brilliant. I never thought I'd turn to religion. I came from a very religious family - when I was a child, I would have to go to church all the time, and it kind of set me off, you know, put me off a bit. But, it's that believing and that needing, that things happen for a purpose - it's very powerful. I'd never thought I'd feel it again; I haven't felt like this since I was a teenager.

\section{Theme 4: Spirituality as Attachment}

P3 says that he has got a lot of bridges to build. He seems aware that this is a apt opportunity for the recovery process at "Penryhn Recovery House". He says he has already started to build them, and if he does well there, he can complete other things that he needs to correct in this way:

My family - I've got a lot of bridges to build. I think if I can do well here... well, I've started to build them anyway; if I do well here I can complete them.

For some participants, spirituality is connectedness and being connected to family, friends, fellowship members, another individual in recovery and those who are not:

P4: Spirituality for me, in a nutshell, is connectedness: being connected to my family, my friends, fellowship members, other participants - in recovery and not in recovery -. P5: Being connected to family, friends and other recovering individuals.

\section{Theme 5: Spirituality as a Coping Mechanism}

According to most of the participants, recovery is definitely a spiritual experience. For them, spirituality is an emotional and logical transformation and means everything to them in the recovery process. They state that spirituality is a kind of coping mechanism. When they encounter a problem, they use spiritual values to overcome it. P4 points out the importance of being tolerant, even with their shortcomings. He also states that values of tolerance, patience, love, and understanding must be practised in life actively:

P4: Self-honesty is for me. I think honesty gets you sober, and tolerance keeps you sober. I think the real test is tolerance and tolerance of others and their shortcomings - that's a quote. True tolerance of others and their shortcomings, that's, for me, the big one. But yeah, I do try to practice tolerance, patience, love, understanding.

Besides, P5 sees that:

P5: Spirituality does help greatly. In all areas of life, though. Realising that your "now" is not your "forever" brings hope. The idea of being part of a "bigger picture" and there being a "higher power" (whether true or not is relevant to each (individual) brings faith and peace of mind, in both good and bad times. Prayer and meditation help you to focus on what makes you happy and what you are grateful for. Exploration and being outdoors reminds us of how small we really are in the grand scheme of things. It's too easy to become obsessed with social politics or the smallest of scales. The universe is a big place. 


\section{Discussion, Conclusion and Future Implications:}

This paper draws on both spiritual counselling services that are shaped by predetermined meanings and values, and secondly, on individuals' perceptions about spirituality through the language of desires, needs, and expectations. The researchers explored ideas of spiritual coping and spiritual wellbeing in terms of meaning, purpose, connectedness, hope, and peace in addiction treatment programs influenced by 12-Step models such as Alcoholics Anonymous (Vandivier, 2015). Also, they investigated how spirituality is defined, perceived, and how the meaning of spirituality is established contextually and experientially by individuals in recovery from addiction. As seen, we can understand a lot about the spiritual experiences from the expressions of individuals in recovery from addiction. Besides, it is understood that addiction involves psychological, social, and spiritual dimensions. In the study, it was observed that spirituality was used as a coping instrument for buffering the sensation of hopelessness and despair often experienced by people in active addiction.

Prison life for some was not much of a recovery process - it was often inadequate for them, while others have found that prison is a way to rehabilitate. Each has his reflection on such a prison experience. On the other hand, every person also has different values in terms of spirituality. Some of them connect with family, friends, and feel The Higher Power in terms of group or God. But it all serves the ultimate term, spirituality. They found in spirituality a way to escape their addiction and to find hope and possibly it opened the gate for them to rethink themselves and to seek improvement in oneself.

Although some people think that rehabilitation programs are not beneficial, while others say that these programs are beneficial and have a significant place for their own rehab stories. It is foreseen that a holistic recovery process will take place when spirituality is integrated with the programs of structured or mutual aid groups. It was also observed that the phenomenon of spirituality was used as a coping mechanism in the reactions shown to cope with the sensation of hopelessness. It also appears that spiritual values give some meaning and purpose to life.

The individuals in active recovery state that some of the experiences they lived through during the active addiction process were spiritual. In particular, they name the intention to change in the healing process and the process of change/recovery as spiritual. The perception of spirituality, which includes a sense of the religious, too, was seen to stimulate hope in individuals. It has also been observed that spirituality keeps alive the values at the core of the recovery experience. Inquiries about the meaning and purpose of life have been dealt with in the spiritual dimension in the experiences. In particular, the prison experience was interpreted as an inner journey or an intention to change. At this point, it was stated that spirituality and values give 
motivation and strength to the individual. Therefore, it is the place of spirituality in many experiences, seeing the whole of the prison experience or prison life as spiritual, that is the most exciting point in this study. In summary, in this study, the central schemes that appear as "Spirituality in Experiences, Spirituality in Values, Spirituality as Meaning/Purpose of Life, Spirituality as Attachment, Spirituality as Coping Mechanism" have been evaluated within the framework of the concept of spirituality. It can be said that the processes and concepts considered as spiritual are change, hope, coping, finding meaning, religion and connectedness.

This study was an initiative to better understand spirituality experienced at prison, a kind of place of change. An additional area of study would conduct including many individuals in recovery. Such a study might be a longer project than that, however the ability to generate a larger sample of the male population for recovery could lead to data that broadens and deepens the understanding of the lived experience of a spiritual transformation (Watts, 2012; Williamson \& Hood, 2013).

\section{References}

Al-Anon, F. G. (2015). Courage to Change. London: Al-Anon Family Group Head Inc.

Alcoholics Anonymous. (2014). The Big Book of Alcoholics Anonymous. New York City: Alcoholics Anonymous World Services.

Baltaci, A. (2018). Nitel Araştırmalarda Örnekleme Yöntemleri ve Örnek Hacmi Sorunsalı Üzerine Kavramsal Bir İnceleme [A Conceptual Review of Sampling Methods and Sample Size Problems in Qualitative Research]. Journal of Bitlis Eren University Institute of Social Sciences, 231-274.

Booth, L. (1987). Alcoholism and the fourth and fifth steps of Alcoholics Anonymous. Journal of Psychoactive Drugs, 269-274.

Breslin, K. T., Reed, M. R., \& Malone, S. B. (2011). An Holistic Approach to Substance Abuse Treatment. Journal of Psychoactive Drugs, 247-251.

Casey, E. S. (2009). Remembering: A phenomenological study. Indiana University Press.

Cook, C. C. (2004). Addiction and spirituality. Addiction, 539-551.

Cook, C. C., Powell, A., \& Sims, A. (Eds.). (2009). Spirituality and Psychiatry. London: RCPsych Publications.

Creswell, J. W. (2009). Research Design Qualitative, Quantitative and Mixed Methods Approaches. London: SAGE.

CSARS Group. (2018, 4 4). Retrieved from CSARS Group: http://csarsg.org.uk/impact-andoutputs-from-the-higher-power-project/

Culliford, L. (2011). The Psychology of Spirituality. London: Jessica Kingslay Publishes.

Culliford, L., \& Eagger, S. (2009). Assessing spiritual needs. In Spirituality and Psychiatry (pp. 16-38). London: RCPsych Publications.

DiClemente, C. C. (2018). Addiction and Change. New York: The Guilford Press.

Dossett, W. (2013). Addiction, spirituality and 12-Step programmes. International Social Work, 56(3), 369-383. 
Dossett, W. (2015). Reflections on the Language of Salvation in Twelve Step Recovery. In H. Bacon, W. Dossett, \& S. Knowles (Eds.), Alternative Salvations (pp. 21-30). Bloomsbury.

Dossett, W. (2017). A daily reprieve contingent on the maintenance of our spiritual condition. Addiction, 112, 942-943.

Fuller, R. C. (2001). Spiritual, But Not Religious. Oxford Universty Press.

Galanter, M., Dermatis, H., Bunt, G., Williams, C., Trujillo, M., \& Steinke, P. (2007). Assessment of spirituality and its relevance to addiction treatment. Journal of Substance Abuse Treatment, $33,257-264$.

Graham, M. D., McDonald, M. J., \& Klaassen, D. W. (2008). A Phenomenological Analysis of Spiritual Seeking: Listening to Quester Voices. The International Journal for the Psychology of Religion, 18(2), 146-163.

Greene, G., \& Nguyen, T. D. (2012). The Role of Connectedness in Relation to Spirituality and Religion in a Twelve-Step Model. Review of European Studies, 179-187.

Heale, R., \& Twycross, A. (2015). Validity and Reliability in Quantitative Studies. Evidence Based Nursing, 18(3), 66-67.

Heelas, P., Woodhead, L., Seel, B., Szerszynski, B., \& Tusting, K. (2005). The Spiritual Revolution: Why Religion Is Giving Way to Spirituality. Blackwell.

Horvath, A. T., \& Velten, E. (2000). Smart Recovery: Addiction Recovery Support from a Cognitive-Behavioral Perspective. Journal of Rational-Emotive \& Cognitive-Behavior Therapy, 18(3), 181-191.

Irudayadason, N. A. (2018). Exploring the Nexus Between Spirituality and Health. MOJ Yoga \& Physical Therapy, 34-38.

Isaac, K., Hay, J., \& Lubetkin, E. (2016). Incorporating Spirituality in Primary Care. Relig Health, 1065-1077.

Kelly, J. F., Stout, R. L., Magill, M., Tonigan, J. S., \& Pagano, M. E. (2011). Spirituality in Recovery: A Lagged Mediational Analysis of Alcoholics Anonymous' Principal Theoretical Mechanism of Behavior Change. Alcoholism: Clinical and Experimental Research, 35(3), 454-463.

Koenig, H. G., King, D. E., \& Carson, V. B. (2012). Handbook of Religion and Health. Oxford: Oxford University Press.

Li, E. C., Feifer, C., \& Strohm, M. (2000). A pilot study: Locus of control and spiritual beliefs in alcoholics anonymous and smart recovery members. Addictive Behaviors, 633-640.

Manning, L. K. (2012). Spirituality as a lived experience: Exploring the essence of spirituality for women in late life. The International Journal of Aging and Human Development, 75(2), 95-113.

Matthew D. Graham, M. J. (2008). A Phenomenological Analysis of Spiritual Seeking: Listening to Quester Voices. The International Journal for the Psychology of Religion, 146-163.

Mizikaci, F. (2015). Değerler Eğitimi ve Eğitim Programları [Values Education and Education Programs ]. Eleştirel Pedagoji, 3-8.

Moustakas, C. (1994). Phenomenological Research Methods. London: SAGE.

Narcotics Anonymous. (2018). Retrieved 4 3, 2018, from www.ukna.org

North Wales Recovery Community. (2018). Retrieved 4 3, 2019, from http://www.nwrc.info/www. nwrc.info/index.html

Ozdogan, O. (2009). Isimsiz Hayatlar [Anonymous Lives]. Ankara: Lotus. 
Pnina, S., \& Jonathan, A. S. (2009). Alcohol and the self: An interpretative phenomenological analysis of the experience of addiction and its impact on the sense of self and identity. Addiction Research and Theory, 152-167.

Poole, R., \& Higgo, R. (2006). Psychiatric interviewing and assessment. Cambridge University Press.

Roman, C. G., Wolff, A., Correa, V., \& Buck, J. (2007). Assessing Intermediate Outcomes of a Faith-Based Residential Prisoner Reentry Program. Research on Social Work Practice, 199-215.

Schwartz, S. H., \& Sagie, G. (2000). Value consensus and importance: A cross-national study. Journal of cross-cultural psychology, 31(4), 465-497.

Shinebourne, P., \& Smith, J. A. (2011). Images of addiction and recovery: An interpretative phenomenological analysis of the experience of addiction and recovery as expressed in visual images. Drugs: education, prevention and policy, 18(5), 313-322.

Sims, A., \& Cook, C. C. (2009). Spirituality in psychiatry. In C. Cook, A. Powell, \& A. Sims (Eds.), Spirituality and psychiatry.

The Higher Power Project. (2018, 4 4). Retrieved from The Higher Power Project: https://www1. chester.ac.uk/theology-and-religious-studies/research/higher-power-project

Tonigan, J. S., N., R. K., \& McCrady, B. S. (2013). Spirituality as a Change Mechanism in 12- Step Programs: A Replication, Extension, and Refinement. Substance Use \& Misuse, 1161-1173.

Watts, R. P. (2012). The lived experience of a spiritual transformation in the everyday lives of alcoholic men new to recovery: A phenomenological study. Doctoral dissertation, Capella University.

Vandivier, A. M. (2015). The lived-experience of spiritual awakening for members of alcoholics anonymous with long-term sobriety: A phenomenological study. Doctoral dissertation, Capella University.

WHO, W. H. (2004). Prevention of Mental Disorders: Effective Interventions and. World Health Organization.

Williamson, W. P., \& Hood, R. W. (2013). Spiritual Transformation: A Phenomenological Study Among Recovering Substance Abusers. Pastoral Psychol, 889-906.

Woodhead, L. (2010). Real Religion And Fuzzy Spirituality? Taking Sides In The Sociology Of Religion. In S. Aupers (Ed.), Religions of Modernity. Brill.

Wright, V. L. (2003). A Phenomenological Exploration of Spirituality Among African American Women Recovering From Substance Abuse. Archives of Psychiatric Nursing, 173-185. 